\title{
Caudal neostigmine with bupivacaine produces a dose-independent analgesic effect in children
}

\author{
[L'administration caudale de néostigmine avec bupivacaïne produit une
}

analgésie non reliée à la dose]

Rajesh Mahajan MD, Vinod K. Grover MD MNAMs, Pramila Chari MD FAMS

Purpose: To evaluate the analgesic efficacy and duration of varying doses of caudal neostigmine with plain bupivacaine and its side effects in children undergoing genito-urinary surgery.

Methods: In a randomized double-blind prospective study 80 boys aged two to eight years scheduled for surgical repair of hypospadias were allocated randomly to one of four groups ( $n=$ 20 each) and received either only caudal $0.25 \%$ plain bupivacaine $0.5 \mathrm{~mL} \cdot \mathrm{kg}^{-1}$ (Group I) or $0.25 \%$ plain bupivacaine $0.5 \mathrm{~mL} \cdot \mathrm{kg}^{-1}$ with neostigmine (Groups II-IV) in doses of 2, 3 and $4 \mu \mathrm{g} \cdot \mathrm{kg}^{-1}$ respectively. Postoperative pain was assessed for $24 \mathrm{hr}$ using an objective pain score. Blood pressure, heart rate, oxygen saturation, total amount of analgesic consumed and adverse effects were also recorded.

Results: The duration of postoperative analgesia in Group I (5.I \pm $2.3 \mathrm{hr}$ ) was significantly shorter than in the other three groups (II | $6.6 \pm 4.9$ hr; III - |7.2 \pm 5.5 hr; IV - 17.0 \pm 5.8 hr; $P<0.05)$. Total analgesic (paracetamol) consumption was significantly more in Group I $(697.6 \pm 240.7 \mathrm{mg})$ than in the groups receiving caudal neostigmine (II - $248.0 \pm 178.4$; III - $270.2 \pm 180.8$ and IV $230.6 \pm 166.9 \mathrm{mg} ; P<0.05)$. Groups II, III and IV were comparable with regards to duration of postoperative analgesia and total analgesic consumption $(P>0.05)$. Incidence of nausea and vomiting were comparable in all four groups. No significant alteration in vital signs or any other adverse effects were observed.

Conclusions: Caudal neostigmine (2, 3 and $\left.4 \mu \mathrm{g} \cdot \mathrm{kg}^{-1}\right)$ with bupivacaine produces a dose-independent analgesic effect ( $\approx 16-17 \mathrm{hr})$ in children as compared to those receiving caudal bupivacaine alone (approximately five hours) and a reduction in postoperative rescue analgesic consumption without increasing the incidence of adverse effects.
Objectif : Évaluer l'efficacité analgésique et la durée de différentes doses de néostigmine caudale avec bupivacaïne simple et ses effets secondaires chez des enfants qui subissent une intervention génito-urinaire.

Méthode : Dans une étude randomisée, prospective et à double insu, 80 garçons de deux à huit ans devant subir la réparation chirurgicale d'un hypospadias ont été répartis au hasard en quatre groupes ( $n=$ 20 chacun) et ont reçu : seulement de la bupivacaïne caudale simple à $0,25 \%\left(0,5 \mathrm{~mL} \cdot \mathrm{kg}^{-1}\right.$ Groupe I) ou de la bupivacaïne simple à 0,25 $\%$ avec néostigmine $\left(0,5 \mathrm{~mL} \cdot \mathrm{kg}^{-1}\right.$, Groupes II-IV) en doses respectives de 2, 3 et $4 \mu \mathrm{g} \cdot \mathrm{kg}^{-1}$. La douleur postopératoire a été évaluée pendant $24 \mathrm{~h}$ selon des scores de douleur objectifs. La tension artérielle, la fréquence cardiaque, la saturation du sang en oxygène, la quantité totale d'analgésiques consommés et les effets secondaires ont été aussi enregistrés.

Résultats : La durée de l'analgésie postopératoire a été significativement plus courte dans le Groupe I $(5,1 \pm 2,3 \mathrm{~h})$ que dans les autres groupes (II - 16,6 \pm 4,9 h; III - 17,2 \pm 5,5 h; IV - 17,0 \pm 5,8 h; $P<0,05)$. La consommation totale d'analgésique (paracétamol) a été significativement plus élevée dans le Groupe I (697,6 \pm 240,7 mg) que dans les groupes avec néostigmine caudale (II - 248,0 \pm I78,4; III - 270,2 \pm 180,8 et IV - 230,6 \pm 166,9 mg; P < 0,05). La durée de l'analgésie postopératoire et la consommation totale d'analgésique $(P>0,05)$ étaient comparables dans les groupes II, III et $I$. L'incidence de nausées et de vomissements a été similaire dans les quatre groupes. Aucune modification significative des signes vitaux ou tout autre effet indésirable n'ont été observés.

Conclusion : Chez des enfants, la néostigmine caudale (2, 3 et $\left.4 \mu \mathrm{kg}^{-1}\right)$ avec bupivacaïne, comparées à la bupivacaïne caudale seule ( 5 h), produit une analgésie non reliée à la dose ( 16-17 h) et une réduction de la consommation postopératoire d'analgésique de secours sans augmenter l'incidence d'effets indésirables.

From the Department of Anaesthesia and Intensive Care, Postgraduate Institute of Medical Education and Research, Chandigarh, India. Address correspondence to: Dr. Vinod K. Grover, H.No.53, Sector 24-A, Chandigarh-160023, India. Phone: 91-172-272-4220; Fax: 91-172-274-4401; E-mail: suman_vinod@yahoo.co.in

Financial support for this clinical project was provided by the Postgraduate Institute of Medical Education and Research, Chandigarh, India. Accepted for publication October 15, 2003.

Revision accepted April 12, 2004. 
$\mathrm{P}$ AIN is a highly unpleasant sensory and emotional experience further complicated in children by their inability to express and react. ${ }^{l}$ Various pharmacological agents and analgesic delivery systems have been employed to avoid under-treatment of pain in children. ${ }^{2}$ Genitourinary surgery is generally associated with considerable pain of long duration. Caudal extradural block with bupivacaine ensures satisfactory analgesia in the initial postoperative period only and becomes ineffective once the block wears off. ${ }^{3,4}$ Various methods have been devised to extend the duration of regional analgesia with local anesthetics. Placement of a catheter poses an inherent risk of infection and delays mobilization. ${ }^{2}$ The use of ketamine, clonidine and opioids is limited because of potential side effects such as nausea, vomiting, sedation and respiratory depression. ${ }^{3-8}$

The role of neostigmine as an analgesic administered by the extradural route is now well established in children and adults.9-12 Co-administration of caudal neostigmine in a dosage of $2 \mu \mathrm{gg} \cdot \mathrm{kg}^{-1}$ with bupivacaine or ropivacaine has been found to provide prolonged analgesia without any adverse effects. ${ }^{9}, 10$ Extradural neostigmine $\left(1,2\right.$ or $\left.4 \mu \mathrm{g} \cdot \mathrm{kg}^{-1}\right)$ with local anesthetic has been found to produce a dose-independent analgesic effect in adult patients without increasing the incidence of adverse effects. ${ }^{11}$ The aim of the present study was to evaluate if incremental doses of extradural neostigmine $\left(2,3\right.$ and $\left.4 \mu \mathrm{g} \cdot \mathrm{kg}^{-1}\right)$ with bupivacaine would improve and/or prolong analgesia for genito-urinary surgery in children without any significant side effects.

\section{Methods}

After approval from the Institutional Ethics Committee and informed consent from the parents, this randomized double-blind study was conducted in 80 healthy male children, ASA physical status I, aged between two to eight years undergoing surgical repair of hypospadias. Children with a known history of bleeding diathesis, allergy to local anesthetics, aspirin ingestion in the preceding week or pre-existing neurological or spinal disease were excluded. All patients were examined a day before surgery. Pulse rate, blood pressure, respiratory rate were recorded and a thorough neurological examination for deep tendon reflexes, muscle tone and power in the limbs was carried out. No premedication was administered. Anesthesia was induced by face mask with halothane and $60 \%$ nitrous oxide $\left(\mathrm{N}_{2} \mathrm{O}\right)$ in oxygen $\left(\mathrm{O}_{2}\right)$. After securing an $i v$ cannula, the trachea was intubated after paralysis with atracurium $0.5 \mathrm{mg} \cdot \mathrm{kg}^{-1}$ and the lungs were ventilated mechanically. Anesthesia was maintained with $60 \% \mathrm{~N}_{2} \mathrm{O}$ in $\mathrm{O}_{2}$ and halothane 0.5 to $2 \%$.
After the induction of anesthesia, patients were turned to the left lateral position and a caudal block was performed using a 23-gauge short bevel needle under sterile conditions. Patients were allocated randomly to one of four groups $(n=20)$ by a computer generated randomization scheme to receive the following drugs by the caudal route; Group I $-0.25 \%$ plain bupivacaine $0.5 \mathrm{~mL} \cdot \mathrm{kg}^{-1}$; Group II $-0.25 \%$ plain bupivacaine $0.5 \mathrm{~mL} \cdot \mathrm{kg}^{-1}$ with neostigmine $2 \mu \mathrm{g} \cdot \mathrm{kg}^{-1}$; Group III - $0.25 \%$ plain bupivacaine $0.5 \mathrm{~mL} \cdot \mathrm{kg}^{-1}$ with neostigmine $3 \mu \mathrm{g} \cdot \mathrm{kg}^{-1}$ and Group IV $-0.25 \%$ plain bupivacaine $0.5 \mathrm{~mL} \cdot \mathrm{kg}^{-1}$ with neostigmine $4 \mu \mathrm{g} \cdot \mathrm{kg}^{-1}$. The investigator administering the blocks was unaware of the randomization. Surgical intervention was allowed ten to $15 \mathrm{~min}$ after the caudal injection.

Heart rate, electrocardiogram (ECG) and $\mathrm{O}_{2}$ saturation $\left(\mathrm{SpO}_{2}\right)$ were monitored continuously and arterial blood pressure was monitored every five minutes during surgery. After the operation, the duration of surgery and time from discontinuation of the volatile anesthetic to tracheal extubation were recorded. Patients were observed for two hours in the recovery room before returning to the ward. ECG and pulse oximetry were monitored continuously. Blood pressure, heart rate, respiratory rate, neurological variables (deep tendon reflexes, muscle tone and power in the limbs) and objective pain scores (see below) were recorded at 30 -min intervals for the first two hours, then every two hours for $24 \mathrm{hr}$ by another investigator unaware of patient grouping. Pain was assessed using an observational scoring system modified from Hannallah and colleagues using five criteria: ${ }^{13}$ crying, movement, agitation, posture and localization of pain. Each criterion scored 0 to 2 to give a total score of 0 to $10.4^{4,13}$ Duration of analgesia was defined as the time interval between placement of the caudal block to the first demand for supplemental analgesia. On evidence of pain, that is if the pain score reached a value of $>3$, children received oral paracetamol 20 $\mathrm{mg} \cdot \mathrm{kg}^{-1}$. The total amount of analgesic given in $24 \mathrm{hr}$ was recorded. Nausea, vomiting, sedation and other adverse effects, if any, were also recorded. Postoperative sedation was assessed according to the sedation score $(0-4)$ used by Maunuksela et al. ${ }^{14}(0=$ fully awake, $1=$ slightly drowsy; 2 = asleep but easily arousable; 3 = fully asleep but arousable and $4=$ fully asleep, not arousable).

Statistical analyses were performed using analysis of variance (ANOVA) Kruskal Wallis test and Fisher's exact test as appropriate. $P<0.05$ was considered significant. 
TABLE Demographic and clinical data

\begin{tabular}{|c|c|c|c|c|}
\hline & Group I & Group II & Group III & Group IV \\
\hline Age (yr) & $6.2 \pm 2.2$ & $6.0 \pm 2.8$ & $5.8 \pm 2.4$ & $5.9 \pm 3.1$ \\
\hline Weight (kg) & $15.7 \pm 4.2$ & $16.2 \pm 4.9$ & $16.2 \pm 5.8$ & $16.8 \pm 6.2$ \\
\hline Respiratory rate $\cdot \mathrm{min}^{-1}$ & $20.4 \pm 1.0$ & $19.4 \pm 1.0$ & $20.2 \pm 1.7$ & $19.8 \pm 1.6$ \\
\hline Heart rate $\cdot \min ^{-1}$ & $113 \pm 11.2$ & $112 \pm 14.2$ & $111 \pm 11.8$ & $114 \pm 12.6$ \\
\hline Systolic BP (mmHg) & $108 \pm 6.9$ & $109 \pm 6.2$ & $108 \pm 6.6$ & $106.3 \pm 8.1$ \\
\hline Diastolic BP (mmHg) & $74.7 \pm 4.0$ & $74.2 \pm 4.5$ & $72.0 \pm 4.2$ & $73.9 \pm 3.9$ \\
\hline $\mathrm{O}_{2}$ saturation $(\%)$ & $98.0 \pm 0.2$ & $98 \pm 0.6$ & $99 \pm 0.1$ & $98.2 \pm 0.6$ \\
\hline Duration of surgery (min) & $81.6 \pm 23.2$ & $82 \pm 19.9$ & $78.2 \pm 21.2$ & $77.3 \pm 20.6$ \\
\hline Duration of general anesthesia (min) & $92.5 \pm 20.2$ & $91 \pm 19.8$ & $88.6 \pm 22.2$ & $86.8 \pm 21.2$ \\
\hline Time of extubation (min) & $10.0 \pm 2.1$ & $9.8 \pm 1.6$ & $9.5 \pm 1.6$ & $9.7 \pm 2.3$ \\
\hline
\end{tabular}

All results mean $\pm \mathrm{SD} . \mathrm{BP}=$ blood pressure. There were no differences between groups $(P>0.05)$.

\section{Results}

All groups were comparable in age, weight, duration of surgery, heart rate, blood pressure, $\mathrm{SpO}_{2}$ and neurological status $(P>0.05$; Table).

Mean time to first administration of rescue analgesia was $5.1 \pm 2.3 \mathrm{hr}$ in Group I, $16.9 \pm 4.9 \mathrm{hr}$ in Group II, $17.2 \pm 5.6 \mathrm{hr}$ in Group III and $17.1 \pm 4.8$ hr in Group IV $(P<0.05$ II, III and IV when compared to Group I; Figure). However, there was no statistically significant difference among Groups II, III and IV. Total analgesic consumption was significantly lower in groups receiving caudal neostigmine as compared to that receiving caudal bupivacaine alone $[(P<$ $0.05)$ Groups $\mathrm{I}=697.6 \pm 240.7 \mathrm{mg}\left(44.4 \mathrm{mg} \cdot \mathrm{kg}^{-1}\right)$, $\mathrm{II}=248.0 \pm 178.4 \mathrm{mg}\left(15.3 \mathrm{mg} \cdot \mathrm{kg}^{-1}\right) ; \mathrm{III}=270.2 \pm$ $180.8 \mathrm{mg}\left(16.6 \mathrm{mg} \cdot \mathrm{kg}^{-1}\right)$ and IV $=230.6 \pm 166.9 \mathrm{mg}$ $\left.\left(13.9 \mathrm{mg} \cdot \mathrm{kg}^{-1}\right)\right]$. There was no significant difference in the incidence of vomiting among the four groups. Vomiting occurred in two children in Group I, three in Group II, four in Group III and three in Group IV $(P>0.05)$. Sedation scores were comparable in all four groups with none of the patients having a sedation score of $>2$ at any time $(P>0.05)$. None of the patients had any episode of fall in $\mathrm{SpO}_{2}$, hypotension, bradycardia or motor weakness. Urinary retention could not be evaluated as all patients were catheterized in the postoperative period. No delayed adverse effects were observed during follow-up.

\section{Discussion}

In the present study, we have confirmed the analgesic efficacy of caudal neostigmine when co-administered with bupivacaine in children. Our clinical research demonstrated a dose-independent analgesic effect of 2,3 and $4 \mu \mathrm{gg} \cdot \mathrm{kg}^{-1}$ of caudal neostigmine co-administered with plain $0.25 \%$ bupivacaine $0.5 \mathrm{~mL} \cdot \mathrm{kg}^{-1}$ for

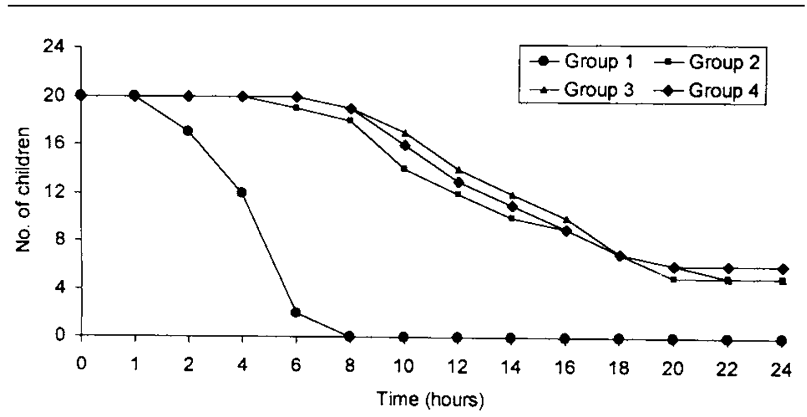

FIGURE Number of children free of pain at varying time intervals in different groups. Group 1 = plain bupivacaine. In groups 2 , 3 and 4 , neostigmine 2,3 and $4 \mu \mathrm{g} \cdot \mathrm{kg}^{-1}$, respectively, was added to plain bupivacaine.

postoperative analgesia in children undergoing genitourinary surgery.

The neuraxial administration of neostigmine is known to produce analgesia in animals, human volunteers and patients with acute postoperative and chronic pain. ${ }^{11,15-18}$ Spinal delivery of the cholinesterase inhibitor neostigmine inhibits the breakdown of the endogenous spinal neurotransmitter acetylcholine which has been shown to produce analgesia. ${ }^{19-21}$ Neuraxial administration of neostigmine increases the concentration of acetylcholine in cerebrospinal fluid and produces antinociception in animals which is blocked by the intrathecal administration of a muscarinic antagonist. ${ }^{15-22}$ The analgesic effect is thought to be mediated via spinal muscarinic $M_{1}$ receptors and supraspinal muscarinic $M_{1}$ and $M_{2}$ and nicotinic cholinergic receptors. ${ }^{15,22}$ Autoradiographic studies 
have shown muscarinic binding in substantia gelatinosa and, to a lesser extent, in the laminae III and V of the dorsal grey matter of the spinal cord, coincident with opioids and adrenergic sites. ${ }^{17}$

Various investigators have reported a dose-independent effect of the neuraxial administration of neostigmine on postoperative pain relief and analgesic requirements. In pregnant patients Krukowski et al. have demonstrated that varying doses of intrathecal $(10,30$ and $100 \mu \mathrm{g})$ provided dose independent analgesia lasting approximately ten hours in all three groups. ${ }^{23}$ Similarly Lauretti et al. have shown dose independent analgesia in patients undergoing vaginal hysterectomy in a dose range of 25 to $75 \mu \mathrm{g}$ intrathecal neostigmine. ${ }^{24}$ The same authors have also demonstrated dose independent analgesia with the combination of $20 \mathrm{mg}$ intrathecal bupivacaine plus 85 mg epidural lidocaine with neostigmine $(1,2$ or 4 $\left.\mu \mathrm{g} \cdot \mathrm{kg}^{-1}\right)$ in patients undergoing knee surgery. ${ }^{11}$

We also demonstrated a similar, dose independent analgesic effect of escalating doses of caudal neostigmine with bupivacaine in children. It may be possible that caudal bupivacaine potentiates the analgesic effect of neostigmine, thereby rendering additive doses of neostigmine ineffective. Alternatively, the lowest dose of neostigmine may have maximally potentiated the analgesic effect of caudal bupivacaine, making higher doses of caudal neostigmine no more effective. Considering the lack of efficacy of neostigmine alone in doses $<10 \mu \mathrm{g} \cdot \mathrm{kg}^{-1},{ }^{12}$ it is not surprising that lower doses combined with bupivacaine may have uniformly potentiated the effect of caudal bupivacaine.

The neuraxial administration of neostigmine has been found to be safe in various animal studies. ${ }^{11,16,25,26}$ Transient motor weakness has been seen with very high doses of intrathecal neostigmine. ${ }^{16,27}$ Caudal neostigmine was not associated with any neurological sign and rapid mobilization was possible in all patients.

As in previous studies, no significant hemodynamic changes were observed. Neuraxial cholinesterase inhibitors counteract the inhibitory effect of local anesthetics on sympathetic nervous activity and may blunt anesthetic induced hypotension in animals and humans. ${ }^{10,11,24}$ Further, neuraxial anesthesia has been found to be virtually free of hemodynamic effects, at least in children up to eight years of age and this may account for the lack of any significant hemodynamic alterations in our study. ${ }^{2}$

Although the use of neuraxial neostigmine has been associated with gastrointestinal side effects such as nausea, vomiting or diarrhea, ${ }^{16}$ these were not encountered in the present study. Lauretti et al. and Roelants et al. have also reported the extradural administration of neostigmine to be devoid of these undesirable side effects. ${ }^{11,26}$ Further, these side effects have been found to be statistically insignificant ${ }^{9,10}$ and independent of the dose of neuraxial neostigmine. ${ }^{11,13,14,24}$ The use of caudal bupivacaine alone has been found to be associated with nausea and vomiting to the extent of 25 to $45 \%, 4,8,13,28$ an incidence similar to that seen with caudal morphine, fentanyl and tramadol. ${ }^{7,8,29}$ It seems that caudal neostigmine in such low doses contributes minimally to nausea and vomiting.

In conclusion, caudal neostigmine in doses of 2 $\mu \mathrm{g} \cdot \mathrm{kg}^{-1}$ combined with $0.25 \%$ bupivacaine 0.5 $\mathrm{mL} \cdot \mathrm{kg}^{-1}$ produces an extended duration of postoperative analgesia with minimal incidence of adverse effects in children undergoing surgery for hypospadias.

\section{References}

1 Visintainer $M A$, Wolfer JA. Psychological preparation for surgical pediatric patients: the effect on children's and parents' stress responses and adjustment. Pediatrics 1975; 56: 187-202.

2 Dalens BJ. Regional anesthesia in children. In: Miller RD (Ed.). Anesthesia, 5th ed. Philadelphia: Churchill Livingstone; 2000: 1549-85.

3 Cook B, Grubb DJ, Aldridge LA, Doyle E. Comparison of the effects of adrenaline, clonidine and ketamine on the duration of caudal analgesic produced by bupivacaine in children. Br J Anaesth 1995; 75: 698-701.

4 Wolf AR, Hughes D, Wade A, Mather SJ, Prys-Roberts $C$. Postoperative analgesia after paediatric orchidopexy: evaluation of a bupivacaine morphine mixture. $\mathrm{Br} \mathrm{J}$ Anaesth 1990; 64: 430-5.

5 Takasaki M, Dobi S, Kawabata $\Upsilon$, Takabashi T. Dosage of lidocaine for caudal anesthesia in infants and children. Anesthesiology 1977; 47: 527-9.

6 Naguib M, Sharif AM, Seraj M, El Gammal M, Dawlatly $A A$. Ketamine for caudal analgesia in children: comparison with caudal bupivacaine. Br J Anaesth 1991; 67: 559-64.

7 Senel AC, Akyol A, Dohman D, Solak M. Caudal bupivacaine-tramadol combination for postoperative analgesia in pediatric hernioraphy. Acta Anaesthesiol Scand 2001; 45: 786-9.

8 Krane EJ, Jacobson LE, Lynn AM, Parrot C, Tyler DC. Caudal morphine for postoperative analgesia in children: a comparison with caudal bupivacaine and intravenous morphine. Anesth Analg 1987; 66: 647-53.

9 Turan A, Memis D, Basaran UN, Karamanlioglu B, Sut $N$. Caudal ropivacaine and neostigmine in pediatric surgery. Anesthesiology 2003; 98: 719-22.

10 Abdulatif $M$, El-Sanabary $M$. Caudal neostigmine, bupivacaine, and their combination for postoperative 
pain management after hypospadias surgery in children. Anesth Analg 2002; 95: 1215-8.

11 Lauretti GR, de Oliveira RD, Reis MP, Juliao MC, Pereira NL. Study of three different doses of epidural neostigmine coadministered with lidocaine for postoperative analgesia. Anesthesiology 1999; 90: 1534-8.

12 Batra YK, Arya VK, Mahajan R, Chari P. Dose response study of caudal neostigmine for postoperative analgesia in paediatric patients undergoing genitourinary surgery. Paediatr Anaesth 2003; 13: 515-21.

13 Hannallab RS, Broadman LM, Belman AB, Abramowitz MD, Epstein BS. Comparison of caudal and illioinguinal/illiohypogastric nerve blocks for control of post-orchiopexy pain in pediatric ambulatory surgery. Anesthesiology 1987; 66: 832-4.

14 Maunuksela EL, Korpela R, Olkkola KT. Double-blind, multiple-dose comparison of buprenorphine and morphine in postoperative pain of children. Br J Anaesth 1988; 60: 48-55.

15 Naguib M, Yaksh TL. Antinociceptive effects of spinal cholinesterase inhibition and isobolographic analysis of the interaction with $\mu$ and $\alpha_{2}$ receptor systems. Anesthesiology 1994; 80: 1338-48.

16 Hood DD, Eisenach JC, Tuttle R. Phase I safety assessment of intrathecal neostigmine methylsulfate in humans. Anesthesiology 1995; 82: 331-43.

17 Lauretti GR, Reis MP, Prado WA, Klamt JG. Doseresponse study of intrathecal morphine versus intrathecal neostigmine, their combination, or placebo for postoperative analgesia in patients undergoing anterior and posterior vaginoplasty. Anesth Analg 1996; 82: 1182-7.

18 Klamt JG, Dos Reis MP, Neto JB, Prado WA. Analgesic effect of subarachnoid neostigmine in two patients with cancer pain. Pain 1996; 66: 389-91.

19 Iwamoto ET, Marion L. Characterization of the antinociception produced by intrathecally administered muscarinic agonists in rats. J Pharmacol Exp Ther 1993; 266: 329-38.

20 Yaksh TL, Dirksen R, Harty GJ. Antinociceptive effects of intrathecally injected cholinomimetic drugs in the rat and cat. Eur J Pharmacol 1985; 117: 81-8.

21 Gordh T Jr, Jansson I, Hartvig P, Gillberg PG, Post C. Interactions between noradrenergic and cholinergic mechanisms involved in spinal nociceptive processing. Acta Anaesthesiol Scand 1989; 33: 39-47.

22 Bouaziz H, Tong C, Eisenach JC. Postoperative analgesia from intrathecal neostigmine in sheep. Anesth Analg 1995; 80: 1140-4.

23 Krukowski JA, Hood DD, Eisenach JC, Mallak KA, Lamar Parker $R$. Intrathecal neostigmine for postcesarean section analgesia: dose response. Anesth Analg 1997; 84: 1269-75.
24 Lauretti GR, Hood DD, Eisenach JC, Pfeifer BL. A multi-center study of intrathecal neostigmine for analgesia following vaginal hysterectomy. Anesthesiology 1998; 89: 913-8.

25 raksh TL, Grafe MR, Malkmus S, Rathbun ML, Eisenach JC. Studies on the safety of chronically administered intrathecal neostigmine methylsulfate in rats and dogs. Anesthesiology 1995; 82: 412-27.

26 Roelants F, Rizzo M, Lavand'homme P. The effect of epidural neostigmine combined with ropivacaine and sufentanil on neuraxial analgesia during labor. Anesth Analg 2003; 96: 1161-6.

27 Kremer $M$. Action of intrathecally injected pyridostigmine, acetylcholine and eserine on the central nervous system in man Q. J Exp Physiol 1942; 31: 337-57.

28 Splinter WM, Reid CW, Roberts DJ, Bass J. Reducing pain after inguinal hernia repair in children. Caudal anesthesia versus keterolac tromethamine.

Anesthesiology 1997; 87: 542-6.

29 Gaitini LA, Somri M, Vaida SJ, et al. Does the addition of fentanyl to bupivacaine in caudal epidural block have an effect on plasma level of catecholamines in children? Anesth Analg 2000; 90: 1029-33. 